\title{
CONTENT ANALYSIS OF ENGLISH TEXTBOOK FOR 11TH GRADE OF SENIOR HIGH SCHOOL ON HOTS CRITERIA
}

\author{
Chintara Mentari Putri ${ }^{\left.\mathrm{a}^{*}\right)}$, Atti Herawati ${ }^{\text {a) }}$, Mursidah Rahmah a) \\ a) Universitas Pakuan, Kota.Bogor, Indonesia \\ ${ }^{*}$ e-mail korespondensi: chintaramentariputri.99@gmail.com
}

\section{Riwayat Artikel}

diterima 24 November 2021 direvisi 11 Desember 2021 disetujui 30 Desember 2021

\begin{abstract}
.
The newest curriculum or well known as national curriculum has four goals in education of Indonesia. One of them is Higher Order Thinking Skills which means the output of teaching and learning process is required to have higher level of thinking. Thus, the Ministry of Education provides textbook for all level of schools; one of them is for Senior High School. This research aimed to investigate if HOTS is accommodated in English textbook provided by the Ministry of Education; focuses on the content of the textbook, in terms of questions and instructions provided and in relation to HOTS criteria which covers C4 (analyze), C5 (evaluate), and C6 (create). This research applied a qualitative method and used documentation and interview as the instruments. There are four respondents consisting of three English teachers from different schools, and one evaluation expert. The finding shows that HOTS have already been accommodated in English textbook. There are 116 of 211 HOTS questions with frequency 55\%, 74 of 252 HOTS instructions with frequency $30 \%$, and factual knowledge as the most dominant knowledge dimension in questions which have 90 of 211 with frequency $43 \%$, and conceptual knowledge as the most dominant knowledge dimension in instructions which have 81 of 252 with frequency $32 \%$. All questions and instructions provided are more about recalling information, guidelines or studies of concepts, describing a factual information and explaining the answer.
\end{abstract}

Keywords: content analysis, textbook, higher order thinking skills

\section{ANALISIS KONTEN BUKU BAHASA INGGRIS SEKOLAH MENENGAH ATAS KELAS 11 TERHADAP KRITERIA HOTS}

\begin{abstract}
Abstrak. Kurikulum terbaru atau yang lebih dikenal dengan kurikulum nasional memiliki empat tujuan dalam pendidikan Indonesia. Salah satunya adalah Higher Order Thinking Skills yang artinya hasil dari proses belajar mengajar dituntut memiliki tingkat berpikir yang lebih tinggi. Oleh karena itu, Kementerian Pendidikan menyediakan buku teks untuk semua jenjang sekolah; salah satunya untuk SMA. Penelitian ini bertujuan untuk mengetahui apakah HOTS diakomodasi dalam buku teks bahasa Inggris yang disediakan oleh Kementerian Pendidikan; berfokus pada pertanyaan dan instruksi yang diberikan dan dalam kaitannya dengan kriteria HOTS yang meliputi C4 (menganalisis), C5 (mengevaluasi), dan C6 (membuat). Penelitian ini menggunakan metode kualitatif dengan instrumen dokumentasi dan wawancara. Ada empat responden yang terdiri dari tiga guru bahasa Inggris dari sekolah yang berbeda, dan satu ahli evaluasi. Temuan ini menunjukkan bahwa HOTS sudah diakomodasi dalam buku teks bahasa Inggris. Terdapat 116 dari 211 soal HOTS dengan frekuensi 55\%, 74 dari 252 instruksi HOTS dengan frekuensi 30\%, dan pengetahuan faktual sebagai dimensi pengetahuan yang paling dominan pada soal yang memiliki 90 dari 211 dengan frekuensi 43\%, dan pengetahuan konseptual sebagai yang paling dominan. dimensi pengetahuan dalam instruksi yang memiliki 81 dari 252 dengan frekuensi 32\%. Semua pertanyaan dan instruksi yang diberikan lebih banyak tentang mengingat informasi, pedoman atau kajian konsep, mendeskripsikan suatu informasi faktual dan menjelaskan jawabannya.
\end{abstract}

Kata Kunci: $\quad$ analisis isi, buku teks, keterampilan berpikir tingkat tinggi

\section{INTRODUCTION}

HOTS which stands for Higher Order Thinking Skills is one of the four things that has been a challenge and become main focus in the newest curriculum in Indonesia. HOTs relates to the students' ability to develop their understanding on the material that they have learned. It means they can create something new based on their understanding. According to Zamani \& Rezvani (2015), definitions of higher-order thinking fall into three categories: (1) those that define higher-order thinking in terms of transfer, (2) in terms of critical thinking, and (3) in terms of problem solving. Schraw et al. (2011: 191) classifies bloom's thinking skill into two categories that is Lower Order Thinking Skills which consists of knowledge, understanding and application; Higher Order Thinking Skills which consists of analysis, synthetic and evaluation. It can be concluded that Higher Order Thinking Skill can be seen at the top three of the Bloom's taxonomy and solving the problem critically is the outcome of higher order thinking skill.

Although the target is the students, the teachers also contribute by giving the exact stimulations; the other contribution in improving students' abilities of HOTs is English textbook. Textbook is one of the elements that has important role in teaching and learning process. Al-Hasanat (2016) stated that textbook is an educational document that reflects content, activities and assessment questions that aim 
at achieving the intended goals. Furthermore, Abdelrahman (2014) claimed that one of the main components of the textbook is the questions and most of the instructional material revolves around them. It means that the questions and instructions in the textbook should be in the higher level of cognitive to support students' critical thinking.

\section{RESEARCH METHODOLOGY}

This research uses qualitative method. It focuses on analyzing the content of English textbook for the 11th grade of Senior High School students by using cognitive domain level of Bloom Taxonomy. The textbook is provided by the Ministry of Education. In addition, the textbook analysis focuses on questions and instructions. In this research, the researcher collects the data through documentation and interview. The following are the techniques and steps of data analysis.

\section{A. Documentation}

The researcher collects the questions and instructions in English textbook for 11th grade of Senior High School and analyzes them based on Bloom taxonomy to acquire their level of cognitive domain.

\section{B. Interview}

The researcher conducts the interview to get more information about the textbook and also the teachers' opinion about HOTS towards instructions and questions provided in the textbook. The researcher conducts the interview through whatsapp application and asks them to answer four questions of the interview. The questions are about content analysis of English textbook for 11th grade of Senior High School on HOTS criteria. Indicators of the questions are: perception of HOTS and questions, and perception of HOTS and instructions. The interviewees are suggested to answer those questions through a voice note, so the answer will be in the form of a voice.

\section{RESEARCH FINDINGS}

\section{A. Data from Documentation}

There are 211 questions that were analyzed. The distribution of knowledge dimension spread over 90 questions (43\%) factual knowledge, 75 questions (36\%) conceptual knowledge, 25 questions (12\%) procedural knowledge, and 20 questions (9\%) metacognitive knowledge. While the distribution of cognitive domain spread out 65 questions (31\%) remember, 29 questions (14\%) understand, a questions $(0,5 \%)$ apply, 48 questions (23\%) analyze, 62 questions (29\%) evaluate, and 6 questions (3\%) create. It can be concluded that there are 95 questions (45\%) are indicates as LOTS and 116 questions $(55 \%)$ are categorized as HOTS. It means the textbook contains more than 50\% HOTS questions. Furthermore, the distribution of knowledge dimension and cognitive domain on the instructions in the textbook. The result can be seen on the table below.
TABEL 1. The Result of Questions' Analysis (C1-C6)

\begin{tabular}{ccccccc}
\hline & $\begin{array}{c}\text { Reme } \\
\text { mber }\end{array}$ & $\begin{array}{c}\text { Under } \\
\text { stand }\end{array}$ & Apply & $\begin{array}{c}\text { Analy } \\
\text { ze }\end{array}$ & $\begin{array}{c}\text { Evalu } \\
\text { ate }\end{array}$ & Create \\
\cline { 2 - 7 } Questio & 65 of & 29 of & 1 of & 48 of & 62 of & 6 of \\
ns & 211 & 211 & 211 & 211 & 211 & 211 \\
$\mathbf{2 1 1}$ & Lower Order Thinking & \multicolumn{3}{c}{ Higher Order Thinking } \\
& \multicolumn{3}{c}{ Skills } & \multicolumn{4}{c}{ Skills } \\
& \multicolumn{3}{c}{95} & & \multicolumn{3}{c}{116} \\
& $45 \%$ & $55 \%$ & \\
\hline
\end{tabular}

TABEL 2. The Result of Questions' Analysis

\begin{tabular}{ccccc}
\hline $\begin{array}{c}\text { Question } \\
\text { S }\end{array}$ & Factual & Conceptual & Procedural & $\begin{array}{c}\text { Metacognit } \\
\text { ive }\end{array}$ \\
\cline { 2 - 5 } $\mathbf{2 1 1}$ & 90 of 211 & 75 of 211 & 25 of 211 & 20 of 211 \\
& $43 \%$ & $36 \%$ & $12 \%$ & $9 \%$ \\
\hline
\end{tabular}

There are 252 instructions that were analyzed. The distribution of knowledge dimension spread over 73 instructions (29\%) factual knowledge, 81 instructions (32\%) conceptual knowledge, 53 instructions $(21 \%)$ procedural knowledge, and 45 instructions (18\%) metacognitive knowledge. While the distribution of cognitive domain spread over 74 instructions (29\%) remember, 61 instructions (24\%) understand, 42 instructions (17\%) apply, 11 instructions (4\%) analyze, 23 instructions (9\%) evaluate, and 41 instructions (16\%) create. It can be concluded that there are 177 instructions $(70 \%)$ categorized s LOTS and 75 instructions (30\%) categorized as HOTS; means that more than less than $50 \%$ instructions categorized as HOTS. The result can be seen on the table below.

TABEL 3. The Result of Instructions' Analysis (C1-C6)

\begin{tabular}{|c|c|c|c|c|c|c|}
\hline \multirow{3}{*}{$\begin{array}{l}\text { Inst } \\
\text { ruct } \\
\text { ions } \\
252\end{array}$} & $\begin{array}{l}\text { Reme } \\
\text { mber }\end{array}$ & $\begin{array}{c}\text { Unders } \\
\text { tand }\end{array}$ & Apply & $\begin{array}{c}\text { Analyz } \\
\text { e }\end{array}$ & $\begin{array}{c}\text { Evalua } \\
\text { te }\end{array}$ & Create \\
\hline & $\begin{array}{c}74 \text { of } \\
252\end{array}$ & $\begin{array}{c}61 \text { of } \\
252\end{array}$ & $\begin{array}{c}42 \text { of } \\
252\end{array}$ & $\begin{array}{c}11 \text { of } \\
252\end{array}$ & $\begin{array}{c}23 \text { of } \\
252\end{array}$ & $\begin{array}{c}41 \text { of } \\
252\end{array}$ \\
\hline & Lower & $\begin{array}{c}\text { der Think } \\
177 \\
70 \%\end{array}$ & g Skills & Higher & $\begin{array}{c}\text { rder Thin } \\
75 \\
30 \%\end{array}$ & ig Skills \\
\hline
\end{tabular}

TABEL 4. The Result of Instructions' Analysis

\begin{tabular}{|c|c|c|c|c|}
\hline Instructio & $\begin{array}{c}\text { Factu } \\
\text { al }\end{array}$ & $\begin{array}{c}\text { Conceptu } \\
\text { al }\end{array}$ & $\begin{array}{c}\text { Procedur } \\
\text { al }\end{array}$ & $\begin{array}{c}\text { Metacogniti } \\
\text { ve }\end{array}$ \\
\hline $\begin{array}{c}\text { ns } \\
252\end{array}$ & $\begin{array}{c}73 \text { of } \\
252\end{array}$ & 81 of 252 & 53 of 252 & 45 of 252 \\
\hline & $29 \%$ & $32 \%$ & $21 \%$ & $18 \%$ \\
\hline
\end{tabular}

\section{B. Data from Interview}

The second instrument is interview. There were four questions asked to three respondents (English teachers) and an evaluation expert. It was done through Whatsapp application; the researcher texted the respondents one by one. The respondents answered it by writing message or sending voice note. The data are the detail information of the textbook and their opinions toward HOTS in the textbook.

The first question is about respondents' opinion related to HOTS questions in the textbook. One respondent says that HOTS has been accommodated in the textbook because there are analyzing questions and creating something. Meanwhile, the other respondents argue that some of the questions are HOTS

The second question is about respondents' opinion related to the form of questions that categorized as HOTS. All the respondents gave the examples of the form of questions 
based on their opinion. Two respondents said the questions that need students' opinion to explain the answer can be categorized as HOTS. The last respondent argued questions that stimulate students' analytical and critical thinking can be categorized as HOTS.

The third questions is about respondents' opinion on HOTS instructions in the textbook. Four respondents argued that some activities use instructions that have high level of cognitive.

The last questions is about respondents' opinion related to the form of instructions that can be categorized as HOTS. Two respondents gave an example of the form of HOTS instruction as "Please analyze this sentences!".

\section{DATA ANALYSIS}

The researcher is going to describe content analysis of English textbook for 11th grade of senior high school on HOTS criteria. The data is analyzed by connecting the result of triangulation with the indicators used in this research. In addition, the following is the explanation of the data that has been analyzed and concluded;

Based on the result of interview, in terms of opinion on High Order Thinking Skill's Questions are; 3 of 4 respondents $(75 \%)$ say that HOTS' question is the questions that lead the students to solve the problem based on their way of thinking, it also leads students' creativity, analytical, and critical thinking. In addition, another one of respondent says that the questions in the textbook have many analyzing and creating questions.

Furthermore, based on the data analysis toward textbook stop bullying now-stand up-speak up, the most dominant cognitive level in the textbook is remember on questions and instruction. It means that recalling information from the material or the textbook is dominant in teaching and learning process. It can be seen in the analysis table that shows 65 of 211 questions are remember and 74 of 252 instructions are remember. Both questions and instructions appear the most frequently, $31 \%$ questions of remember, $29 \%$ instructions of remember. However, in analysis table, it also can be seen the result of the distribution cognitive level and knowledge dimension. For analysis table of questions, it can be seen that the total of questions in $\mathrm{C} 4, \mathrm{C} 5$ and $\mathrm{C} 6$ are more than $\mathrm{C} 1, \mathrm{C} 2$, and $\mathrm{C} 3$. After having calculated, there are 116 of 211 questions which are in C4, C5, and C6 with frequency $55 \%$. It means that the question provided in the textbook have 55\% HOTS; means that those lead students' critical thinking. The respondent gives an example of HOTS' questions as "What can we learn from the dialogue?", it supports the result of analysis the data which is also found same form of questions "What lesson did you learn from this story?" (C4). It implies that the data from interview supports the result of analysis data.

While in table analysis of instruction, it can be seen that the total of instructions in $\mathrm{C} 4, \mathrm{C} 5$, and $\mathrm{C} 6$ are less than $\mathrm{C} 1, \mathrm{C} 2$, and C3. After having calculated, there are only 75 of 252 instructions which are in $\mathrm{C} 4, \mathrm{C} 5$, and C6 with frequency $30 \%$. It means that instructions provided in the textbook have only $30 \%$ HOTS. As the result of analysis data as "... what would you do about it." it is supported by the respondent's example of HOTS' instruction stated in excerpt $8 \#$ “....write the possible solution to the problem". Although those instructions have different form, they have the same meaning which ask the students to solve the problem.

Furthermore, in analysis table of knowledge dimension, factual knowledge is the most dominant knowledge dimension on the questions provided; there are 90 Of 211 questions with frequency $43 \%$. It means that kinds of knowledge to be learned in this textbook has many questions that lead the students to recall information from the textbook, guidelines, or studies on the concept. While conceptual knowledge is the most dominant knowledge dimension on the instructions provided; there are 81 of 252 instructions with frequency $32 \%$. It means that most of instruction provided are conceptual knowledge that lead the students to further describe the factual information and explain their answer.

Briefly, the result of this result showed that questions and instructions in the textbook have 55\% questions and $30 \%$ instructions which are in $\mathrm{C} 4$ (analysis), $\mathrm{C} 5$ (synthetic/evaluate), and C6 (evaluation/create). It was in line with Schraw et al. (2011: 191) bloom's thinking skill into two categories that is Lower Order Thinking Skills which consists of knowledge, understanding and application; Higher Order Thinking Skills which consists of analysis, synthetic and evaluation. Zamani \& Rezvani (2015) also said that definitions of higher-order thinking fall into three categories: (1) those that define higher-order thinking in terms of transfer, (2) it in terms of critical thinking, and (3) in terms of problem solving. There are $43 \%$ questions that include in factual knowledge which means about recalling information; 32\% instructions that include in conceptual knowledge which means about further describe the factual information. It was line with Forhand (2010) states that the knowledge dimensions (or the kind of knowledge to be learned) and the cognitive process dimension (or the process used to be learned) are important for teaching and learning process. Anderson and Krathwohl (2001) explain Factual knowledge encompasses the basic elements that experts use in communicating about their academic discipline, understanding it, and organizing it systematically. Conceptual knowledge includes knowledge of categories and classifications and the relationships between and among them-more complex, organized knowledge forms; it includes schemas, mental models, or implicit or explicit theories in different cognitive psychological models.

\section{CONCLUSION}

HOTS questions means the questions that lead the students to solve the problem based on their way of thinking and leads students' creativity, analytical, and critical thinking. Based on the data from documentation and interview, it is found that there are many analyzing and creating questions in the textbook. It is shown by the result of analysis table which says that questions in the textbook have 116 HOTS questions with frequency $55 \%$. Meanwhile, the instructions provided in the textbook only have 75 HOTS instructions with frequency $30 \%$. However, both questions and instructions are dominated by the $\mathrm{C} 1$ cognitive level. 
Furthermore, in knowledge dimension, the most dominant knowledge dimension between questions and instructions is different. In the questions, factual knowledge is the most dominant which have 90 questions with frequency $43 \%$. While in instructions, the most dominant is conceptual knowledge which has 81 instructions with frequency $32 \%$. Additionally, the result says that only 20 out of 211 questions with frequency $9 \%$ and 45 of 252 instructions with frequency $18 \%$ that indicates metacognitive knowledge. Therefore, metacognitive knowledge is the least knowledge dimension in both questions and instructions in the textbook.

\section{REFERENCES}

Abdelrahman, D. M. (2014). An Analysis of the Tenth Grade English Language Textbooks Questions in Jordan Based on the Revised Edition of Bloom's Taxonomy. Journal of Education and Practice, 139-151.

Al-hasanat, H. A. (2016). Analyzing assessment questions in an Arabic textbook (communication skills) for eighth grade in Jordan according to Bloom's taxonomy of levels of knowledge aims. World Journal of Education, $6(2), 68-81$.

Anderson, L.W., and Krathwohl, D.R. (2001). A Taxonomy of Learning, Teaching, and Assessing: A Revision of Bloom's Taxonomy of Educational Objectives. New York: Longman.

Forhand, M.(2010). Bloom's Taxonomy. Available at http://projects.coe.uga.edu/epltt/index.php?title =Bloom's_Taxonomy

Schraw, Gregory, Robinson, DH. (2011). Assessment Of Higer Order Thinking Skillss. America: Information Age Publishing

Zamani, G. and Rezvani, R. (2015). 'HOTS' in Iran's Official Textbooks: Implications for Material Design and Student Learning. Journal of Applied Linguistics and Language Research, 138-151. 